\title{
ЗНАЧЕНИЕ СЕМЬИ В ВОСПИТАНИИ МУСУЛЬМАНСКОЙ МОЛОДЕЖИ
}

\section{THE IMPORTANCE OF THE FAMILY IN THE UPBRINGING OF MUSLIM YOUTH \\ K. Khasabova}

Summary: Modern youth belonging to the Muslim denomination live in new socio-political conditions. They were born after the regime change in the country, after the onset of a wave of religious revival, which entailed transformations in the sphere of spirituality, family, and value orientations. The article analyzes the problems and values of Muslim youth (from among the residents of the Republic of Dagestan). Understanding the main problems and values of youth is very important, given the complex and multidimensional specifics of modern Muslim youth. Attention is paid to the problem of perception of the family by young people, the role of the family in their socialization, life priorities.

Keywords: youth, family, Islam, values, Sharia.

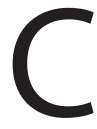
овременная молодежь, принадлежащая к мусульманской конфессии, проживает в новых общественно-политических условиях. Они были рождены после смены советского режима в стране, после наступления волны религиозного возрождения, что повлекло за собой трансформации в сфере духовности, семьи, ценностных ориентиров.

Весь этот спектр процессов, протекающих параллельно в разных сферах жизни общества, но в то же время отличающихся взаимозависимостью и взаимовлиянием, отразился на жизни мусульманской молодежи, на ее восприятии духовности, на ее приоритетных ценностях.

Ислам как религия возник в начале VII в. Такие нравственные ценности дагестанского народа, как уважение к родителям, почитание старших, гостеприимство, дружба, любовь к Родине, труду и т.д. пришли из глубины веков. Общеизвестны имена Ибн-Сины, Улугбека, АльФараби и многих других мусульманских ученых, труды которых вошли в мировую сокровищницу знаний. Свой вклад исламский мир внес и в воспитание, считавшееся важнейшим делом родителей, общества, государства. Недаром во всех низших образовательных исламских заведениях первейшее внимание уделялось именно вопросам нравственного характера.

В статье используются теоретические наработки и аналитические материалы ведущих исследователей ценностей мусульманской молодежи в мире.

\author{
Хасабова Карина Андреевна \\ Соискатель, Южный Федеральный Университет \\ sahara039@mail.ru
}

Аннотация: Современная молодежь, принадлежащая к мусульманской конфессии, проживает в новых общественно-политических условиях. Они были рождены после смены режима в стране, после наступления волны религиозного возрождения, что повлекло за собой трансформации в сфере духовности, семьи, ценностных ориентиров. В статье анализируются проблемы и ценности мусульманской молодежи (из числа жителей Республики Дагестан). Понимание основных проблем и ценностей молодежи очень важно, учитывая сложную и многоаспектную специфику современной мусульманской молодежи. Внимание уделено проблеме восприятия семьи молодежью, роли семьи в их социализации, жизненных приоритетах.

Ключевые слова: молодежь, семья, ислам, ценности, шариат.

Также в статье подвергаются анализу результаты проведенных автором в республиках Северного Кавказа социологических исследований. Например, аналитический отчет по результатам качественного исследования по итогам проведения фокусированных интервью «Радикальная идеология: проблемы, профилактика, решение» в области формирования информационной политики и превенции радикализации молодежи (2017 г.), проведенного автором в рамках проекта ООО «РА «Реклама Кавказ» и Министерства печати и информации Республики Дагестан, и исследования «Вопросы религии и религиозного экстремизма в Республике Дагестан» [1], проведенного автором в рамках проекта Центра исследования глобальных вопросов современности и региональных проблем «Кавказ. Мир. Развитие» среди молодежи в Республике Дагестан.

Мусульманская религия регламентирует все стороны семейной жизни людей, исповедующих ислам, поэтому этно-педагогику дагестанской семьи нельзя рассматривать в отрыве от исламских ценностей, воспитательная ориентация которых не вызывает сомнений.

Ислам выступает духовно-нравственной основой системы семейного воспитания. Как известно, религия является составной частью самобытной культуры народа. Г.Н. Волков называет ее девятым из десяти суммирующихся этно-педагогических инвариантов (факторов). Десятый - пример-идеал (идея-символ, событие-символ, личность-символ), он суммирует все предыдущие в том 
числе и религию - со всеми святыми, их житиями, молитвами, песнопениями, проповедями, мусульманскими праздниками. Все это полнее всего представлено именно в семье.

Далее представим наиболее актуальные проблемы молодежи.

Результаты исследования показали, что среди особенностей региона, влияющих на ценности, распространенные в регионе, можно выделить религиозный исламский фактор как доминирующую в обществе религию, играющую важную роль в жизни населения и, соответственно, являющуюся базисом для формирования ценностей. Другая особенность региона сила народных традиций в сознании и жизни граждан, влияние адатов (норм обычного права) [1].

Общество здесь смешанное, почти всегда и неразделимо одновременно сочетает в себе исламские, этнические, традиционные и светские принципы.

Молодежь как группа, изначально психологически подверженная радикализму, отличается эмоциональной гиперчувствительностью, склонностью к максимализму, протестности, догматизму [2].

Дагестанскую молодежь отличает высокая степень религиозности.

В дагестанском обществе высокая религиозность (отметили 92,5 \% дагестанцев). Следовательно, возможность влиять и воздействовать на народ здесь высока.

Молодежь, особенно самый сложный ее возраст - от 16 до 20 лет, очень восприимчива тогда, когда проходит этап психологической адаптации во взрослый мир и взросления.

Свои проблемы молодежь связывает с ситуативными затруднениями: «учеба... проблема в адаптации в университете... проблема нехватки времени... распределения нагрузки... нехватка сна... нагрузка».

Наиболее часто среди проблем молодежи Дагестана отмечали «употребление запрещенных веществ...наркотики, курение, алкоголь».

Некоторые отметили такие проблемы, как коррупция... востребованность получаемого образования... низкий уровень культуры...

В основном, молодежь разделилась на тех, у кого особых «проблем нет», «все и так хорошо», «с внешним миром и социумом проблем нет», «здесь, в общем, хорошо живется», но есть «проблемы личные», «у кого-то в семье, у кого-то с учебой», «отношения...», и тех, кто считает, что проблемы существуют, и они связаны с материальным фактором и трудоустройством: «денежное и материальное положение взрослых», «вопрос в возможностях родителей», «работа нам потом», «и сейчас работа тоже для нас проблема».

Наиболее часто озвучиваемая проблема молодежи отношения с родителями: «проблема отцов и детей», «есть такие люди, у кого в этом возрасте плохие отношения с родителями» и «таких много».

Проблема «воспитания» и «культуры» также во всех группах озвучивалась как актуальная, а также «неуважение к старшим», поведение, в частности «в транспорте».

Отношение к проблемам разное: «Есть философские проблемы, и есть проблемы, с которыми мы ежедневно встречаемся... Философские проблемы неразрешимы. А проблемы повседневные, бытовые разрешимы. Но важно, с какой точки зрения их воспринимать, чтобы они решались» [3].

Настроение учащейся молодежи зависит «от количества пар», «от нагрузки», «успехов», «зависит от многого», «от уроков, даже от погоды». То есть наличие проблем или отношение к ним зависит зачастую от ситуации.

Настроения в молодежной среде также сложно однозначно охарактеризовать, так как они разные и даже противоположные. Часть молодежи отметила, что, в общем, все хорошо, но бытовое и повседневное иногда способно омрачить настроение.

Но у части молодежи «настроения нет», и они отмечают «депрессивность» и «агрессивность» молодежи, причина которых кроется в «материальном факторе». Особенно часто подобную проблему озвучивали респонденты мужского пола: «вот окончу университет, а работы нет, жениться тоже надо, дом строить...».

Как показали исследования, проведенные среди молодежи, молодые люди отмечают существование следующих проблем:

- личные проблемы (повседневные, бытовые, психологические);

- материальные проблемы и затруднения (трудоустройство, подработка, возможности родителей);

- культура и воспитание;

- проблема «отцов и детей».

Проблема отсутствия взаимопонимания с родителями - это «конфликт», который может проявляться с двух сторон, в двух крайностях, каждая из которых иногда выступает одним из факторов допущения радикализации и оказывается довольно значительной [4]. 
С одной стороны, проблема «отцов и детей» проявляется в недостаточном внимании к детям и проблемам своих детей, в отсутствии доверия и понимания, в непонимании и игнорировании изменений в их поведении. С другой стороны, в излишнем контроле, давлении, навязывании своего мнения и в нежелании понять их позицию, что вызывает отторжение и протест.

Важнейшей задачей молодого человека и путем в успешное будущее является воспитание и получение хорошего образования. Стремительный процесс реисламизации привел к тому, что со светским образованием стало конкурировать исламское религиозное образование. Молодежь уезжала учиться в зарубежные страны, были открыты местные религиозные учебные заведе- ния.

Результаты исследования показывают, что в обществе высоко ценится образование, и воспитание должно совмещать и светское, и религиозное, т.е. человек должен знать свою религию, но при этом быть грамотным. Правовое сознание, несмотря на условия полиюридизма, достаточно развито, но в то же время полиюридизм накладывает свой отпечаток, который нельзя игнорировать.

Важно развивать духовность, не впадать в крайности и модные новые тенденции, не допустить «отчуждения», создания «параллельных обществ» [2]. Ведущая роль здесь у духовных лиц и образованной элиты.

\section{ЛИТЕРАТУРА}

1. Barbara Franz. Europe's Muslim Youth: An Inquiry into the Politics of Discrimination, Relative Deprivation, and Identity Formation. Mediterranean Quarterly. 2007. - 18:1. - 89-112.

2. Сиражудинова С.В. К проблеме радикализации молодежи в Республике Дагестан // Известия Иркутского государственного университета. Серия «Политология. Религиоведение». - 2017. - Т. 20. - С. 26-33.

3. Бердяев Н.А. Размышления $0 б$ эросе / Н.А. Бердяев // Эрос и личность. М., 1989

4. Соловьев В.С. Духовные основы жизни / В.С. Соловьев. 3-е изд. Спб., 1897. 177 с.

(с) Хасабова Карина Андреевна (sahara039@mail.ru).

Журнал «Современная наука: актуальные проблемы теории и практики»

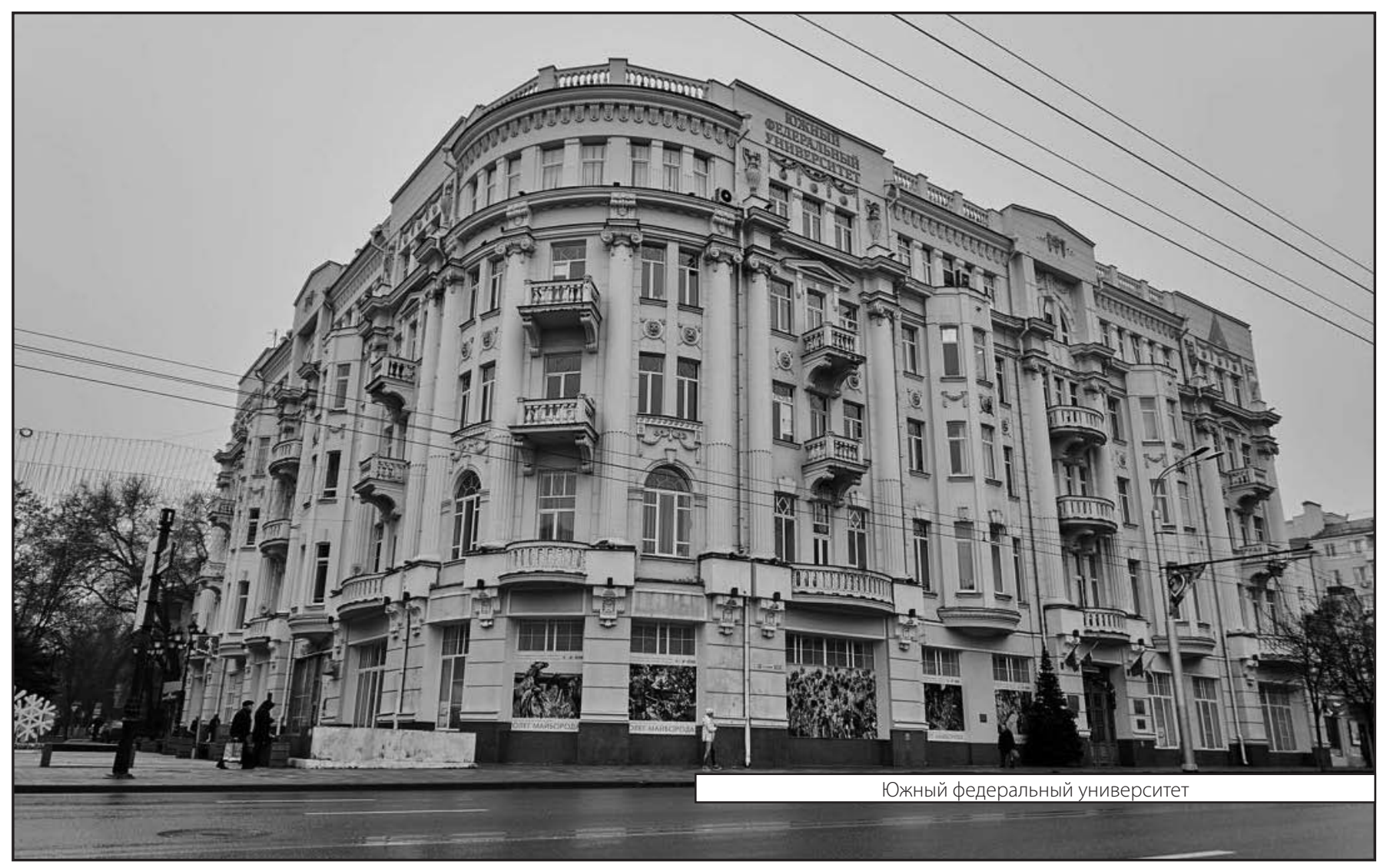

